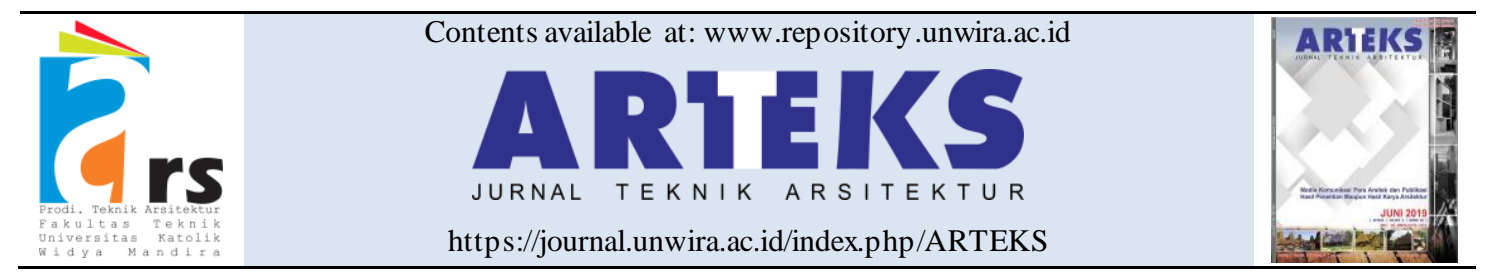

Research paper

doi: 10.30822/arteks.v6i1.365

\title{
Application of reused material concept in the rusunawa planning
}

\author{
Shirleen Christiana Wibowo, Yohanes Basuki Dwisusanto*(i) \\ Master of Architecture Study Program, Faculty of Engineering, \\ Universitas Katolik Parahyangan, Jl. Ciumbuleuit no. 94, Bandung, Indonesia
}

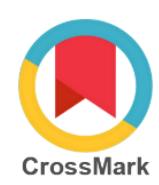

\begin{tabular}{|c|c|}
\hline ARTICLE INFO & ABSTRACT \\
\hline $\begin{array}{l}\text { Article history: } \\
\text { Received January 04, } 2020 \\
\text { Received in revised form June 13, } 2020 \\
\text { Accepted September 15, } 2020 \\
\text { Available online April 01, } 2021 \\
\text { Keywords: } \\
\text { Slums } \\
\text { Reused shipping containers } \\
\text { Rental flats } \\
\\
\text { *Corresponding author: Yohanes Basuki } \\
\text { Dwisusanto } \\
\text { Architecture Study Program, } \\
\text { Faculty of Engineering, } \\
\text { Universitas Katolik Parahyangan, Indonesia } \\
\text { Email: jbase@ @unpar.ac.id } \\
\text { ORCID: https://orcid.org/0000-0003-2686- } \\
\text { 5048 }\end{array}$ & $\begin{array}{l}\text { The need for adequate and affordable housing drives the government } \\
\text { to implement the rusunawa (low-cost housing) development } \\
\text { program in various regions. Futhermore, the government promotes } \\
\text { utilization of different replacement materials to optimize the cost and } \\
\text { duration of rusunawa development, including reused shipping } \\
\text { container. This research discusses the feasibility study of reused } \\
\text { shipping containers as substitute material in the design planning of } \\
\text { the Rusunawa prototype unit construction. It is a qualitative } \\
\text { research that uses case study and statistical data-sets through } \\
\text { literature review, precedent study analysis and field surveys. The } \\
\text { results provided the standard guideline for designing Rusunawa } \\
\text { units made from reused shipping containers and prototype typology } \\
\text { units based on the occupant's type. }\end{array}$ \\
\hline
\end{tabular}

\section{Introduction}

Slums and unsuitable settlements continue to grow in Indonesians (Mahagarmitha 2018). Various development programs are continuously promoted and developed to accommodate people's needs, especially Low-Income Communities (MBR). One of the most outstanding development programs is the construction of low-cost building or rusunawa (Pemerintah Pusat RI 2011). However, the procurement of rusunawa does not necessarily solve the problem of housing needs suitable for living. The Minister of PUPR in the 2018 Property Expo stated that the problems surrounding the development of rusunawa in Indonesia are centred on the development of unit and layout designs, structuring building mass, and regulations and development financing. According to the Minister of Public Works
Regulation Number 05/PRT/M/2007, the technical requirements in the design of rusunawa should meet the building layout standarda, as well as the building reliability with the following planning criteria (Menteri Pekerjaan Umum Republik Indonesia 2007).

Building requirements

These include requirements for location and intensity (GSB/KDB/KLB, etc.), architecture (appearance/facade, interior design, circulation, parking, etc.), and environmental impact requirements.

Building reliability requirements

Include safety (structure and fire), health (ventilation, lighting, sanitation, etc.), comfort (space, air, visual, vibration and noise), and convenience (acces sibility).

This research initiates the design of rusunawa units by utilizing alternative materials, specifically reused shipping containers. 


\section{Method}

This study discusses the feasibility of using reused shipping containers as alternative materials for rusunawa design units. It uses the literature study method and compares it with 2 case studies in the form of awakened residential and 1 building made of reused shipping containers. From the feasibility study, the basic guidelines/criteria for rusunawa planning are made from reused shipping containers.

Based on these standard guidelines, the design of unit typology is planned based on the type of occupant. Design analysis refers to the study of the Support-Infill System theory (Habraken, Boekholt, Thijssen, et al. 1976).

Reused shipping container

Containers are crates or boxes that meet technical requirements of the International Organization for Standardization (ISO) 668 as a means of transporting goods used in various modes, both land and sea (ISO 2013) (figure 1). Containers are considered effective because they can load various types of goods and save shipping costs (Levinson 2006).

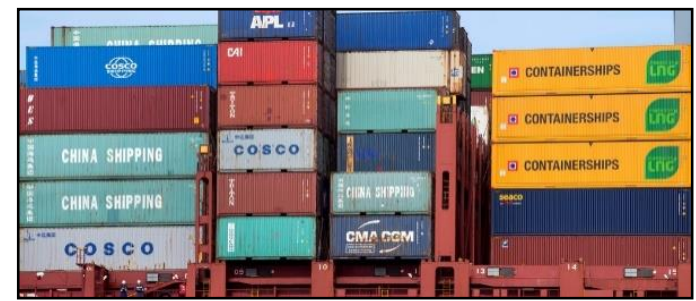

Figure 1. Shipping container

Source: (Routley and Creative Director \& Writer 2018)

Shipping containers are generally made of steel material (Cor-Ten Steel), have a tightly closed surface, and hinged doors (hinged doors) equipped with rubber gaskets and locking rods. Their structure is built from a steel frame. The walls are made of corrugated shaped stiffened panels consisting of steel, aluminium, fibre-reinforced polymer, or a combination of these three materials (figure 2).

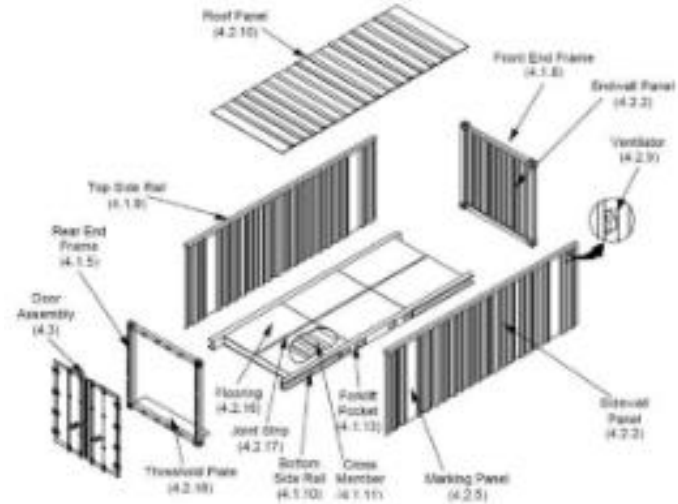

Figure 2. Forming elements of a shipping container Source: (Manaadiar 2013)

According to Ismail (2015), there is a special type of container used to transport goods and can be safely converted into residential, particularly the Intermodel Steel Building Unit (ISBU) or more the High Cube Container (Ismail et al. 2017). This container is designed with insulation for inner space comfort, sound dampening and fire protection (Robinson and Swindells 2012). Potential use of reused shipping container

Due to the development of residential building design in various countries, the utilization of reused shipping containers is quite significant. Similar to conventionalmaterials, reused shipping containers also have advantages and disadvantages. Bender(2016) reported 4 potential uses of reused shipping containers as substitute materials, including adaptability, availability, sustainability, and efficiency (Bender 2016).

Adaptability

Adaptability includes strength, age (life span) and container durability.

1. Strength

Based on ISO standards, containers withstand loads up to 24 tons, or equivalent to a stack of 6 fully loaded units, without the support of additional structures (ISO 2013). This is because they are built from prefabricated steel structures with tested strength has been tested.

2. Age (life span)

The life span of the container usage depends on the type and load. Generally, containers are used for 10-15 years before they are sold or converted. After this duration, their condition decreases with a little rust, scratches, and some holes in the surface. According to Bender (2016), with periodic maintenance (Bender 2016), containers can last up to 50-60 years (Nunes 2009). 


\section{Durability}

Containers are made of special technology steel known as Cor-Ten Steel. Furthermore, Steel is produced as weathering structure to withstand the weather and corrosion resistance. However, regular maintenance is needed to maximize the condition of the container's condition, including sand-blasting and repainting with iron paint. Availability

According to World Shipping Council estimates, more than 30 million shipping containers operate throughout the world. However, more than 2 million container units were in the "retirement" period, abandoned in the depot area (Radwan 2015). These containers can be reused in different ways.

Sustainability

Sustainability is examined in 2 aspects, economics and ecology/environment.

1. Economy

The use of reused shipping containers may save rusunawa construction costs because they are relatively cheaper compared to conventional construction methods.

Based on the RAB rusunawa, Menanggai village, Gayungan, Surabaya built in 2016, the costs incurred for the construction were Rp. $35,836,025,000$ (5 floor of rental flat with an area of 4,299.7 $\mathrm{m}^{2}$ ), or $\pm \operatorname{Rp} 8,500,000$ per $\mathrm{m}^{2}$.

Shipping container price ranges from $\mathrm{Rp}$. $15,000,000$ to Rp. $30,000,000$ per unit (depending on the size, type and age of the container). Compared to the construction price using conventional materials, the costs using reused shipping containers is Rp. 750,000 to Rp. $1,050,000 \mathrm{per} \mathrm{m}^{2}$. Based on these rough estimates, reused shipping containers are far cheaper and more affordable.

Apart from cheaper unit prices, construction costs with reused shipping containers are more efficient because the construction duration is much faster with a relatively smaller number of workers (Madkour and El 2018). However, it is also important to consider the transportation cost to the construction site (Ismail et al. 2017).

2. Ecology/environment

The impact of reused shipping containers utilization on the environment, including the following.

a. Reducing container waste (Pisinger 2002). Utilization of reused shipping containers can reduce $3500 \mathrm{~kg}$ of iron waste (Zberea 2016).

b. Minimize construction waste (low waste construction).

\section{Efficiency}

Containers are modular prefabricated steel structures with a patent shape and size. This makes construction with container material easier. It does not require time and energy during construction using conventional methods (Madkour 2017).

Although it is relatively easy and fast to build, the modular form limits flexibility in designing residential units due to consideration of building utility and structures. There are several examples of shipping container module placement (figure 3).
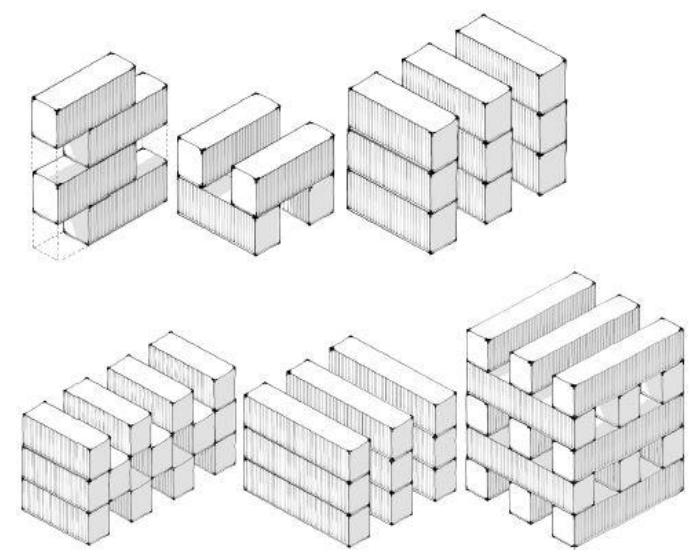

Figure 3. Shipping container configuration form Source: (Botes 2013)

Based on the potential described earlier, there are several requirements for using reused shipping containers, especially for residential functions (related to rusunawa unit design criteria) (table 1).

Table 1. Criteria for the use of reused shipping container for rusunawa units

\begin{tabular}{ll}
\hline Building layout & \\
\hline Location & $\begin{array}{l}\text { Appropriate land use. Near the } \\
\text { port/depot area. }\end{array}$ \\
\hline Look/facade & $\begin{array}{l}\text { Does not interfere with the } \\
\text { visual environment (glare). }\end{array}$ \\
\hline Environmental impact & $\begin{array}{l}\text { Does not damage the } \\
\text { protection/reserve area. }\end{array}$ \\
\hline The building reliability & \\
\hline Safety (structure) & $\begin{array}{l}\text { Prefabricated steel structures } \\
\text { withstand loads of up to 24 } \\
\text { tons/6 piles of container units. } \\
\text { The container age also affects } \\
\text { the structure's safety. Used } \\
\text { containers might last 50-60 } \\
\text { years, with regular } \\
\text { maintenance. }\end{array}$ \\
\hline Safety (fire) & $\begin{array}{l}\text { ISBU Container has a fire } \\
\text { protection system with }\end{array}$ \\
\hline
\end{tabular}




\begin{tabular}{|c|c|}
\hline & $\begin{array}{l}\text { insulation on the interior walls } \\
\text { and floors. } \\
\text { However, fire protection } \\
\text { systems are still needed, such } \\
\text { as hydrants, sprinklers, etc. }\end{array}$ \\
\hline Health (air) & $\begin{array}{l}\text { Ventilation in containers is } \\
\text { needed by modifying the unit } \\
\text { and placing openings. } \\
\text { Therefore, air exchange occurs. } \\
\text { Artificial ventilation can also } \\
\text { be used in the interior of } \\
\text { container units, such as fans, } \\
\text { air conditioners \& exhaust } \\
\text { fans. }\end{array}$ \\
\hline Health (light) & $\begin{array}{l}\text { The container is a waterproof } \\
\text { closed steel box, hence needs } \\
\text { modification to get natural } \\
\text { lighting. } \\
\text { The addition of artificial } \\
\text { lighting is also needed, without } \\
\text { disturbing the occupant's } \\
\text { eyesight. }\end{array}$ \\
\hline Health (sanitation) & $\begin{array}{l}\text { Special pipelines need to be } \\
\text { made for clean, dirty, rain } \\
\text { waters because the container } \\
\text { struct ure does not include } \\
\text { utility lines. }\end{array}$ \\
\hline Comfort (room) & $\begin{array}{l}\text { Although the container shape is } \\
\text { patent, an effective layout and } \\
\text { furnace arrangement results in } \\
\text { a comfortable living } \\
\text { environment. } \\
\text { The required area st andard } \\
\text { refers to the need for fresh air. }\end{array}$ \\
\hline Comfort (air) & $\begin{array}{l}\text { Containers generally smell } \\
\text { certain chemical subst ances } \\
\text { and may dist urb the comfort of } \\
\text { occupants. } \\
\text { Ventilation Placement helps } \\
\text { eliminate the odor. } \\
\text { Furthermore, the use of exhaust } \\
\text { fans facilit ates air circulation in } \\
\text { the unit. }\end{array}$ \\
\hline $\begin{array}{l}\text { Comfort (thermal and } \\
\text { noisy) }\end{array}$ & $\begin{array}{l}\text { Apart from relying on natural } \\
\text { ventilation, additional } \\
\text { insulation on walls and floors } \\
\text { reduces heat and noise. } \\
\text { Insulation that can be used } \\
\text { includes polyurethane foam, } \\
\text { rock wool, plywood, etc. } \\
\text { (Prastiwi et al., 2015). }\end{array}$ \\
\hline
\end{tabular}

The following section compares how to apply criteria in table 1 with the real condition of several study cases, consisting of 2 buildings with occupancy functions (pre-sedent study results) and 1 building with public functions (field survey results), built with reused material container shipping.

Case study 1 - Cité A Docks, Le Havre, France (precedent study)
Cité A Docks is a dormitory building consisting of 100 units covering $24 \mathrm{~m}^{2}$ per unit, built from a combination of reused shipping containers of 20 Feet and 40 Feet arranged up to 4 floors (Radwan 2015) (figure 4).

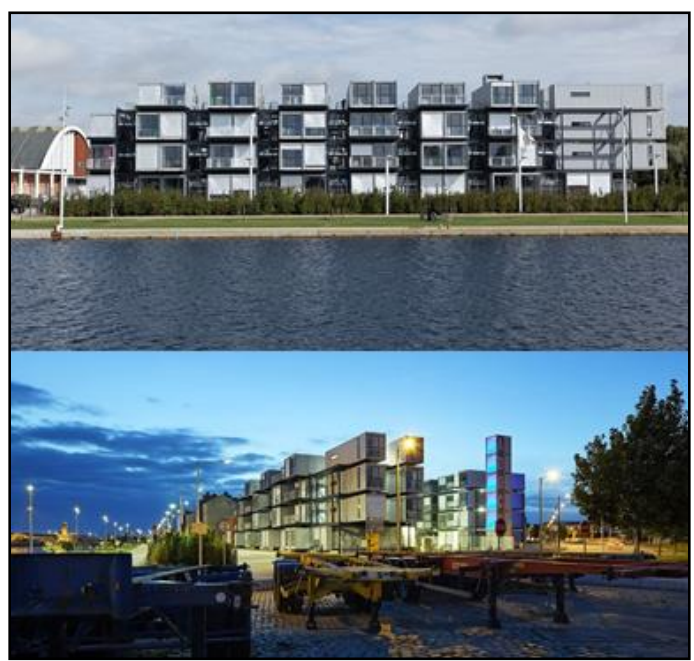

Figure 4. A view of Cité A Docks, Le Havre, France Source: (Cattani Architects 2010)

The problem raised in this project is the comfortable and affordable housing for students (table 2).

Table 2. Checklist of building reliability criteria on Cité A Docks

\begin{tabular}{lcl}
\hline Building reliability & criteria \\
\hline $\begin{array}{l}\text { Safety } \\
\text { (structure) }\end{array}$ & $\checkmark$ & $\begin{array}{l}\text { Additional steel structures are used } \\
\text { to support the container. }\end{array}$ \\
\hline Safety (fire) & $\checkmark$ & $\begin{array}{l}\text { Added } 40 \text { cm firewall insulation, } \\
\text { including rubber coating bet ween } \\
\text { the container units. }\end{array}$ \\
\hline Health (air) & $\checkmark$ & $\begin{array}{l}\text { The width of the container is } \\
\text { modified and placed openings for } \\
\text { natural ventilation. }\end{array}$ \\
& $\begin{array}{l}\text { No artificial ventilation was found, } \\
\text { including air conditioners and } \\
\text { exhaust fans inside the unit. }\end{array}$ \\
\hline Health (light) & $\checkmark$ & $\begin{array}{l}\text { The wide side of the container was } \\
\text { modified, and glass openings were } \\
\text { placed for natural lighting. } \\
\text { Lights on the walls were placed on } \\
\text { each cont ainer unit. }\end{array}$ \\
\hline $\begin{array}{l}\text { Health } \\
\text { (sanitation) }\end{array}$ & $\checkmark$ & $\begin{array}{l}\text { Though, unknown, it is assumed to } \\
\text { be well designed. }\end{array}$ \\
\hline $\begin{array}{l}\text { Comfort } \\
\text { (room) }\end{array}$ & $\checkmark$ & $\begin{array}{l}\text { Based on the minimum area } \\
\text { standard for residents of 1 person, } \\
\text { an area of } 14.4 \mathrm{~m}^{2} / \text { unit is required. } \\
\text { The unit area of } 24 \mathrm{~m}^{2} \text { meets the } \\
\text { required minimum area standard. }\end{array}$ \\
\hline Comfort (air) & $\checkmark$ & $\begin{array}{l}\text { Achieved with the opening of each } \\
\text { unit. }\end{array}$ \\
\hline &
\end{tabular}




\section{Building reliability criteria}

Comfort $\checkmark$ Insulation installation helps muffle

(thermal and

sound and noise.

noisy)

Source: (Radwan 2015)

Case study 2 - Meath Court, Hope Gardens, Ealing (precedent study)

Meath Court is a low-cost housing building made of 20 Feet reused shipping containers, arranged in 4 floors. There are 60 residential units, consisting of 8 studio units, 20 1LDK units, and 32 2LDK units built for \pm 288 homeless people. The construction of the Meath Court only took 24 weeks (figure 5).

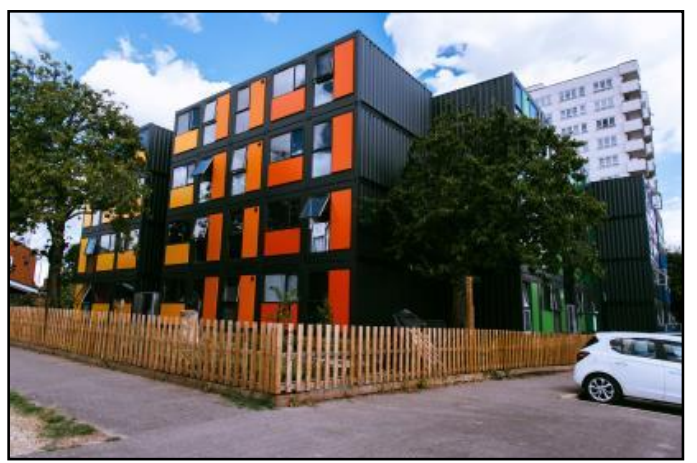

Figure 5. Meath Court, London

Source: (Spinks 2019)

Table 3. Checklist of building reliability criteria at Meath Court

\begin{tabular}{|c|c|c|}
\hline \multicolumn{3}{|c|}{ Building reliability criteria } \\
\hline $\begin{array}{l}\text { Safety } \\
\text { (structure) }\end{array}$ & $\checkmark$ & $\begin{array}{l}\text { There are no additional structures, } \\
\text { though the container has rigid } \\
\text { structures. }\end{array}$ \\
\hline Safety (fire) & $\checkmark$ & $\begin{array}{l}\text { Added } 40 \mathrm{~cm} \text { firewall insulation, } \\
\text { including rubber coat ing bet ween } \\
\text { the container units. }\end{array}$ \\
\hline Health (air) & $\checkmark$ & $\begin{array}{l}\text { The width of the container is } \\
\text { modified, and openings are placed } \\
\text { for nat ural ventilation. } \\
\text { Artificial ventilation is inst alled, } \\
\text { including air conditioners and } \\
\text { exhaust fans in each container unit. }\end{array}$ \\
\hline Health (light) & $\checkmark$ & $\begin{array}{l}\text { The wide side of the container was } \\
\text { modified and glass opening placed } \\
\text { for nat ural lighting. } \\
\text { Lights were placed on the ceiling } \\
\text { of each container unit. }\end{array}$ \\
\hline $\begin{array}{l}\text { Health } \\
\text { (sanitation) }\end{array}$ & $\checkmark$ & $\begin{array}{l}\text { Unknown, but assumed to be well } \\
\text { designed. }\end{array}$ \\
\hline $\begin{array}{l}\text { Comfort } \\
\text { (room) }\end{array}$ & $\bar{x}$ & $\begin{array}{l}\text { Based on the occupants ' } \\
\text { testimonies, the space in each unit } \\
\text { is crowded. They often st ore goods } \\
\text { in the corridor. }\end{array}$ \\
\hline $\begin{array}{l}\text { Comfort (air } \\
\text { and thermal) }\end{array}$ & $x$ & $\begin{array}{l}\text { Although there are openings and } \\
\text { radiators installed in each unit, } \\
\text { some residents claim to be stuffy, } \\
\text { especially in summer. }\end{array}$ \\
\hline
\end{tabular}

\begin{tabular}{ll}
\hline Building reliability criteria \\
\hline $\begin{array}{l}\text { Comfort } \\
\text { (noisy) }\end{array}$ & Not known. \\
\hline
\end{tabular}

Case study 3 - Amin Library, Malang (field survey)

The Amin Library was built using 7 reused shipping containers of 20 and 40 Feet arranged up to 3 floors, with dental poly (ground floor) and library (floors 2-3) (figure 6).

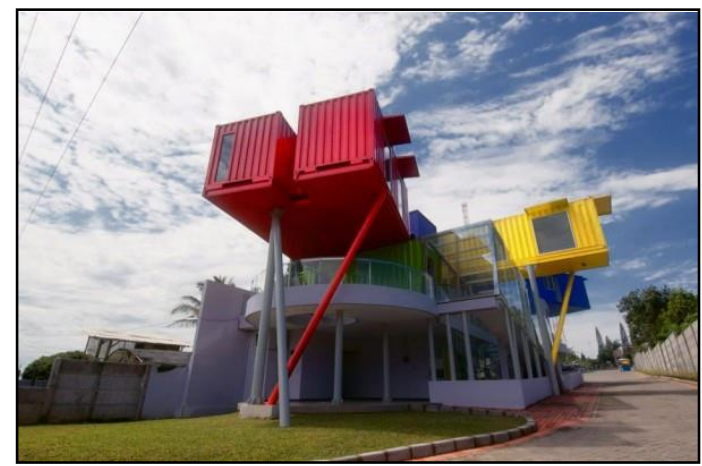

Figure 6. Amin Library, Malang

Source: (Maya 2018)

Each container is given a different colour for different functions and activities (figure 7).

- Red container $\rightarrow$ Science and technology reading room, made of 2 containers 20 feet;

- Green container $\rightarrow$ Receiver room, made of 1 container 20 feet:

- Yellow container $\rightarrow$ Women's reading room, made of 40 feet containers;

- Blue container $\rightarrow$ General reading room, made of 3 containers 40 feet.

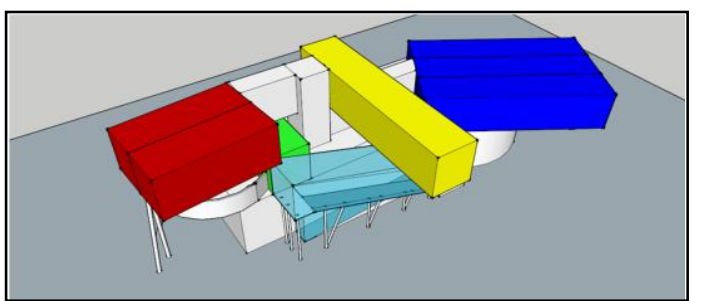

Figure 7. Colour for different functions and activities at Amin Library, Malang

Generally, all building structures consist of steel to facilitate construction. Access from the ground to the second floor uses steel structure and construction designed as a ramp. Also, there is access from the 2 nd to the 3rd floor using stairs with steel construction (figure 8). 


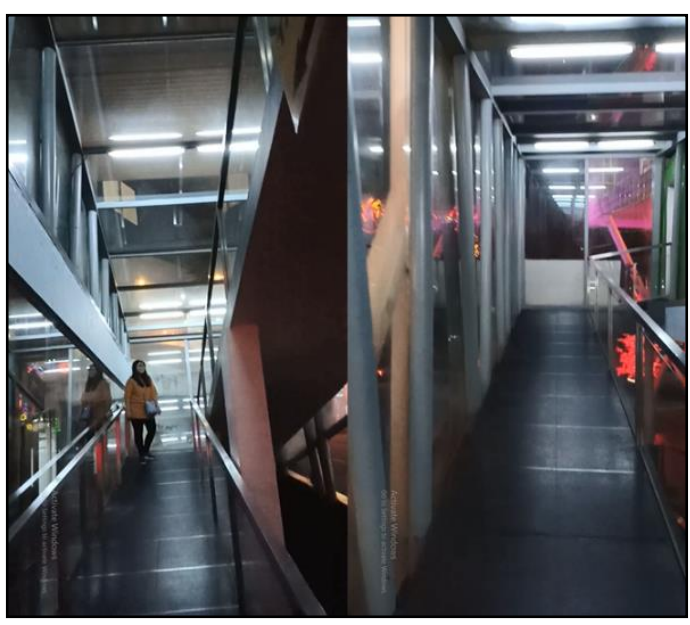

Figure 8. Amin, Batu, Malang Library access and circulation

Table 4. Checklist of building reliability criteria at Amin Library

\begin{tabular}{|c|c|c|}
\hline \multicolumn{3}{|c|}{ Building reliability criteria } \\
\hline $\begin{array}{l}\text { Safety } \\
\text { (structure) }\end{array}$ & $\checkmark$ & $\begin{array}{l}\text { There are additional steel } \\
\text { structures to strengthen the } \\
\text { container structure. }\end{array}$ \\
\hline Safety (fire) & $\checkmark$ & $\begin{array}{l}\text { Added } 10 \mathrm{~cm} \text { plywood insulation } \\
\text { on the interior wall. }\end{array}$ \\
\hline Health (air) & $\checkmark$ & $\begin{array}{l}\text { The sides of the container are } \\
\text { modified, and openings are placed } \\
\text { for natural ventilation. } \\
\text { Artificial ventilation is inst alled, } \\
\text { including air conditioners and } \\
\text { exhaust fans in each container unit. }\end{array}$ \\
\hline Health (light) & $\checkmark$ & $\begin{array}{l}\text { The wide side of the container was } \\
\text { modified, and glass openings were } \\
\text { placed for nat ural lighting. } \\
\text { Lights are placed on the ceiling in } \\
\text { each cont ainer unit. }\end{array}$ \\
\hline $\begin{array}{l}\text { Health } \\
\text { (sanitation) }\end{array}$ & $\checkmark$ & $\begin{array}{l}\text { Though unknown, it is assumed to } \\
\text { be well designed. }\end{array}$ \\
\hline $\begin{array}{l}\text { Comfort } \\
\text { (room) }\end{array}$ & $\checkmark$ & $\begin{array}{l}\text { The placement of furniture and } \\
\text { circulation arrangements is quite } \\
\text { good. Therefore, there is no } \\
\text { collision when } 2 \text { people pass each } \\
\text { other. }\end{array}$ \\
\hline $\begin{array}{l}\text { Comfort (air } \\
\text { and thermal) }\end{array}$ & $x$ & $\begin{array}{l}\text { Although exhaust and AC are } \\
\text { installed in each unit, the room } \\
\text { feels stuffy and smells of } \\
\text { chemicals when the artificial } \\
\text { ventilation is turned off. }\end{array}$ \\
\hline $\begin{array}{l}\text { Comfort } \\
\text { (noisy) }\end{array}$ & 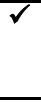 & $\begin{array}{l}\text { The design of container units is } \\
\text { arranged for to sound does not } \\
\text { penetrate bet ween spaces. }\end{array}$ \\
\hline
\end{tabular}

In conclusion, the technical criteria of residential units' design are made from reused shipping containers, technical guidelines synthesis results, precedent studies and field surveys.
Table 5. Technical criteria for rusunawa residential unit design made from reused shipping container

\begin{tabular}{|c|c|}
\hline Criteria & Description \\
\hline Safety (structure) & $\begin{array}{l}\text { May use additional structures or not } \\
\text { since both are safe. }\end{array}$ \\
\hline Safety (fire) & $\begin{array}{l}\text { Need to add insulation to the } \\
\text { interior walls and floors of each } \\
\text { unit, and the installation of fire } \\
\text { protection systems, such as } \\
\text { hydrants, sprinklers, etc.. }\end{array}$ \\
\hline Health (air) & $\begin{array}{l}\text { Natural ventilation is possible by } \\
\text { modifying container units and } \\
\text { placing openings for active air } \\
\text { exchange. }\end{array}$ \\
\hline Health (light) & $\begin{array}{l}\text { Natural lighting is at tained by } \\
\text { modifying the unit, and placing } \\
\text { openings for sunlight can enter the } \\
\text { housing unit. }\end{array}$ \\
\hline Health (sanitation) & $\begin{array}{l}\text { The container st ructure needs to be } \\
\text { modified to create utility pipelines. }\end{array}$ \\
\hline Comfort (room) & $\begin{array}{l}\text { It is necessary to consider the } \\
\text { minimum st andard area needed } \\
\text { based on the type of occupant, and } \\
\text { therefore an effective layout unit } \\
\text { and furnit ure components can be } \\
\text { designed. }\end{array}$ \\
\hline Comfort (air) & $\begin{array}{l}\text { In cert ain location and climate } \\
\text { conditions, additional artificial } \\
\text { ventilation is needed as air } \\
\text { conditioners and exhaust fans. }\end{array}$ \\
\hline Comfort (ligth) & $\begin{array}{l}\text { Artificial lighting is needed as a } \\
\text { light at night or dark. }\end{array}$ \\
\hline $\begin{array}{l}\text { Comfort (thermal, } \\
\text { noisy, vibrate) }\end{array}$ & $\begin{array}{l}\text { Insulation should be installed on } \\
\text { interior walls and cont ainer floors } \\
\text { to reduce external heat. }\end{array}$ \\
\hline
\end{tabular}

Several other requirements related to the physical condition of the reused shipping container to be used as residential Rusunawa (Woods 2015), include:

1. Containers must be waterproof, no gaps emitting light or air, no holes in the floor or roof of containers used, the hinges installed be in good condition.

2. Used containers should be free of chemical toxins (Baur et al. 2015).

3. The container should be free of moss. If found moss, maintenance needs to be carried out in the form of spraying a solution containing salt or a similar compound that is not harmful to health.

4. Where possible, used containers are free from corrosion. However, if there is corrosion, it needs maintenance by sand-blasting or by repainting.

From the precedent study, the types of residential units and reused shipping container units used include the following.

1. Studio type $\rightarrow$ Cité A Docks (1 unit of 40 feet) $-24 \mathrm{~m}^{2}$; Meath Court (1 unit of 20 feet) 
2. Type 1 Living, Dining, Kitchen (LDK) Meath Court ( 2 units of 20 feet)

3. Type 2 Living, Dining, Kitchen (LDK) $\rightarrow$ Meath Court (2 units of 20 Feet)

\section{Result and discussion}

Rusunawa design prototype with reused shipping container

Based on the technical criteria in table 5, a prototype layout unit and rusunawa mass is designed with reused shipping containers. Therefore, it is necessary to examine the needs of space based on the type of rusunawa occupants.

Occupant type and rusunawa space requirement

Referring to this research problem, the mass design and layout of the flat units are currently ineffective and inefficient. They do not accommodate the development needs of occupants (Estaji 2017). Therefore, it is vital to examine the occupant's types and the effective space requirements needed. The occupant's types are divided into the following.

1. Single (1-2 inhabitants);

2. Young family without children (2 inhabitants);

3. Family with 1 child (3 inhabitants);

4. Families with 2 children (4 inhabitants).

The following table 6 , table 7 , and table 8 shows the broad requirements for each type of flat occupant, according to the minimum area standard and fresh air requirements. This is followed by data on space requirements, along with the dimensions of the space that needs to be accommodated in rusunawa units made from reused shipping containers.

Table 6. Minimum floor area based on flats occupants' type

\begin{tabular}{lll}
\hline Occupants type & $\begin{array}{l}\text { L. Min } \\
\left(\mathbf{m}^{\mathbf{2}}\right)\end{array}$ & $\begin{array}{l}\text { L. Msx } \\
\left(\mathbf{m}^{\mathbf{2}}\right)\end{array}$ \\
\hline Single (adult) & 9.60 & 14.40 \\
\hline Young family & 19.20 & 28.80 \\
\hline Family + 1 child & 24.00 & 36.00 \\
\hline Family + 2 children & 28.80 & 43.20 \\
\hline
\end{tabular}

Table 7. Data needs for space

\begin{tabular}{lll}
\hline Room name & User & Activity \\
\hline Living room & Occupants & Socialize \\
\hline & Guest & \\
\hline Family room & Occupants & Relax \\
\hline & & Eat \\
\hline & & Work \\
\hline Bedroom & Occupants & Rest \\
\hline
\end{tabular}

\begin{tabular}{lll}
\hline Room name & User & Activity \\
\hline & & Relax \\
\hline Service room & Occupants & Toilet \\
\hline & & Dry in the sun \\
\hline Utility room & Officer & Maintenance \\
\hline Corridor & Every one & Circulation \\
\hline & & Socialize \\
\hline
\end{tabular}

Source: (Hartinisari 2018)

Table 8. Dimension of unit space in flats

\begin{tabular}{llll}
\hline Room name & $\begin{array}{l}\text { Lenghty } \\
(\mathbf{m})\end{array}$ & $\begin{array}{l}\text { Wide } \\
(\mathbf{m})\end{array}$ & $\begin{array}{l}\text { Total } \\
\left(\mathbf{m}^{2}\right)\end{array}$ \\
\hline Living room & 3.00 & 2.00 & 6.00 \\
\hline Family room & & 2.60 & 5.20 \\
\hline Bedroom & 2.00 & 1.60 & 4.96 \\
\hline Kitchen & 3.10 & 1.80 & 3.60 \\
\hline Toilet & 2.00 & 2.00 & 1.75 \\
\hline Dry area & 0.87 & 0.60 & 0.36 \\
\hline Utility & 0.60 & 1.60 & - \\
\hline Corridor & - & &
\end{tabular}

Source: (Sanjaya and Tobing 2019)

The entire data needs to be examined further to obtain an effective layout of the unit layouts to suit the needs of each occupant. Therefore, the design analysis is conducted based on the Open Building Principles (Habraken, Boekholt, Thyssen, et al. 1976).

Design analysis with Open Building Principles According to Habraken, to obtain an effective layout order, it is necessary to understand the 2 main components underlying the Open Building Principles, including, support and infill components. The support component in this study was represented by a reused HC Shipping Container unit, measuring 20 and 40 feet. The infill component is represented by constructional components, such as walls, floors, ceilings, corridors, and furniture.

There are 4 stages of analysis for producing an effective unit layout based on the needs of each occupant type.

1. Zone and margin analysis

2. Sector analysis

3. Basic analysis

4. Sub-variation analysis

Zone and margin analysis

Zone and margin analysis is carried out to determine the composition of functions in a single unit of residence and to the relationship between functions and effective quantities. It involves dividing activities into 3 spatial categories, namely: general/public (zone $\alpha$ ), special/private (zone $\beta$ ), and service (zone $\gamma$ ) (table 9). Margins are areas between zones, such as corridors and 
utilities. The following is the division of space based on zone and margin characteristics.

Table 9. Spatial distribution based on zone and margin characteristics

\begin{tabular}{|c|c|c|c|c|}
\hline Room name & $\begin{array}{l}\text { Zone } \\
\alpha\end{array}$ & $\begin{array}{l}\text { Zone } \\
\text { 及 }\end{array}$ & $\begin{array}{l}\text { Zone } \\
\gamma\end{array}$ & Margin \\
\hline Living room & O & & & \\
\hline Family room & O & & & \\
\hline Bedroom & & 0 & & \\
\hline Toilet & & O & & \\
\hline Kitchen & & & 0 & \\
\hline Hallway & & & & O \\
\hline Utility & & & & 0 \\
\hline Public Area & & & & 0 \\
\hline Corridor & & & & 0 \\
\hline
\end{tabular}

Sector analys is

Sector analysis determines the possibility of unit typology formed from 20 feet container units according to the space requirements of each occupant type. Synchronization between the analysis results of precedents, occupant types and spatial data needs, concluded 3 types of rusunawa units with 20 feet containers (table 10).

Table 10. Ty pology of residential units based on sector analy sis results

\begin{tabular}{|c|c|c|}
\hline Type unit & $\begin{array}{l}\text { Inhabitant } \\
\text { total }\end{array}$ & Unit typology \\
\hline $\begin{array}{l}\text { Studio } \\
1 \text { unit of } 20 \text { feet } \\
\text { container }\end{array}$ & 1 Inhabitant & \\
\hline $\begin{array}{l}1 \text { LDK } \\
11 / 2 \text { units of a } 20 \\
\text { feet container }\end{array}$ & $1-2$ Inhabitant & \\
\hline $\begin{array}{l}\text { 2 LDK } \\
2 \text { units of } 20 \\
\text { feet container }\end{array}$ & $2-4$ Inhabitant & \\
\hline
\end{tabular}

Basic variation analys is

Basic variation analysis indicates variations or combinations of functions accommodated by each sector (table 11).

Table 11. Basic variations of functions placement in each unit

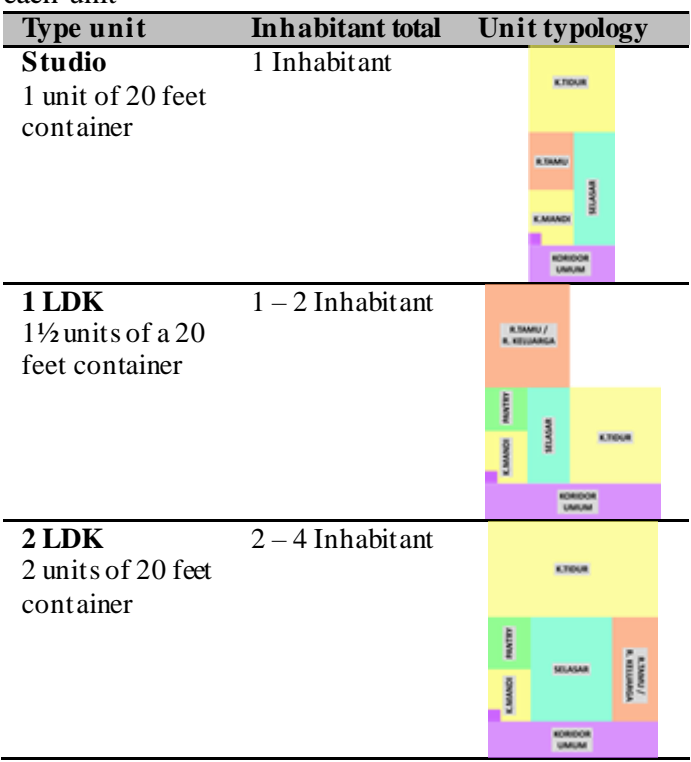

Color and space function description

$\rightarrow$ Living room/family room

$\rightarrow$ Bedroom; bathroom

$\rightarrow$ Kitchen/pantry

$\rightarrow$ Hallway

$\rightarrow$ Corridor and public areas

Sub-variation analys is

The final analysis stage, sub-variations analys is, is the stage of placing infill components, in the form of constructional and furniture elements into each function in each unit type (table 12).

Table 12. Residential unit variations based on sector analy sis reults

\begin{tabular}{llll} 
& Studio type & $\begin{array}{l}\text { Type 1 Living, Dining, } \\
\text { Kitchen }(\mathbf{L D K})\end{array}$ & $\begin{array}{l}\text { Type 2 Living, Dining, Kitchen } \\
\text { (LDK) }\end{array}$ \\
\hline Large & $\mathbf{1 4 . 8 8 \mathbf { ~ m } ^ { 2 }}$ & $\mathbf{2 2 . 2 5 \mathbf { ~ m } ^ { 2 }}$ & $\mathbf{2 9 . 6 4 \mathbf { ~ m } ^ { 2 }}$ \\
\hline Infill & Construction: & Construction: & Construction: \\
components & - Gypsum wall & - Gypsum wall & - Gypsum wall \\
\hline
\end{tabular}




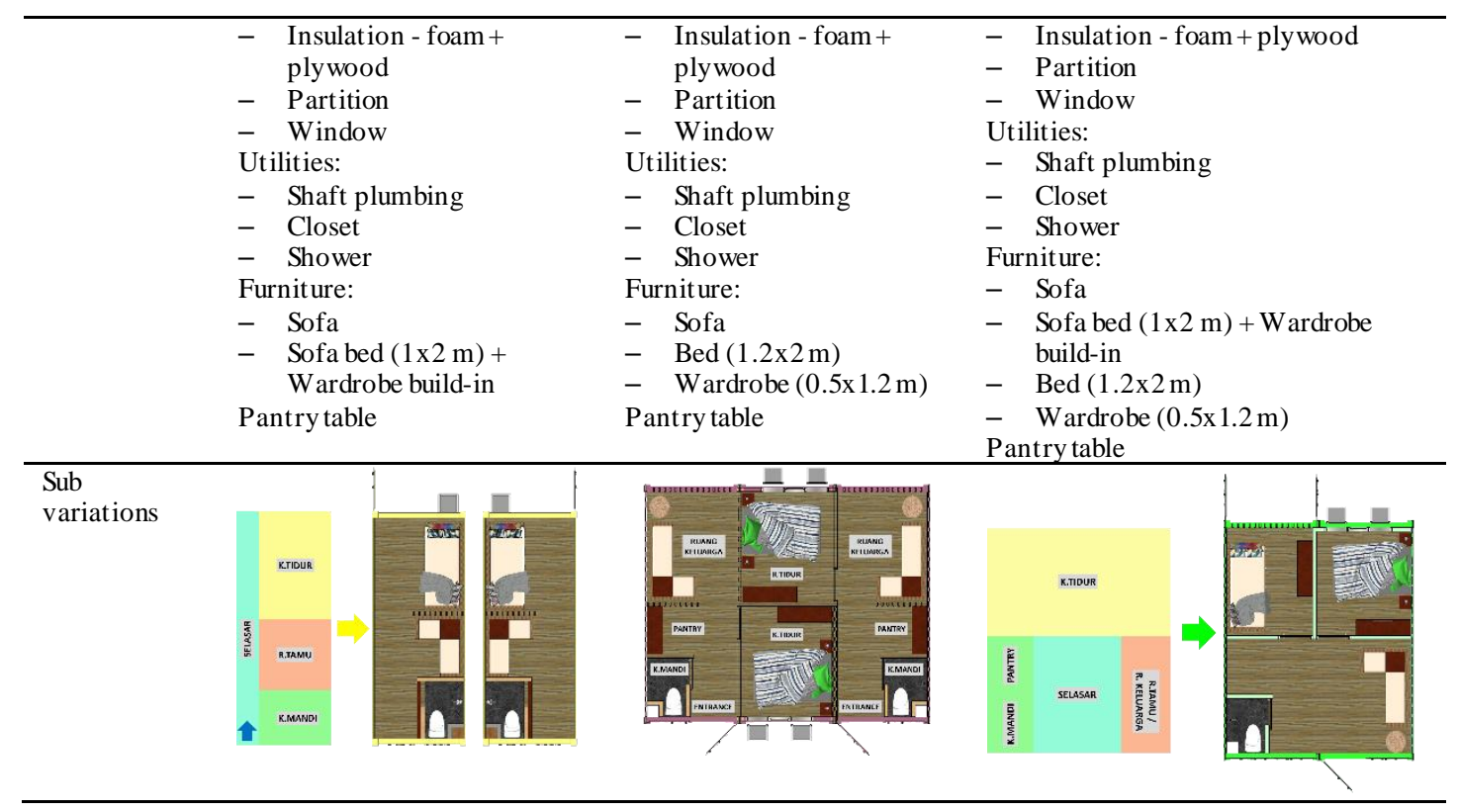

Concepts of building units and mass

Based on the flats Development Guidelines, Rusunawa is built from 5 floors, with the ground floor being a commercial area and the 4 floors above as dwellings.

In the rusunawa design made from reused shipping containers, the concept adopted is an independent flat, where occupants generate their income through empowerment, such as urban farming. The following is the prototype layout and the number of container units needed (figure 9).
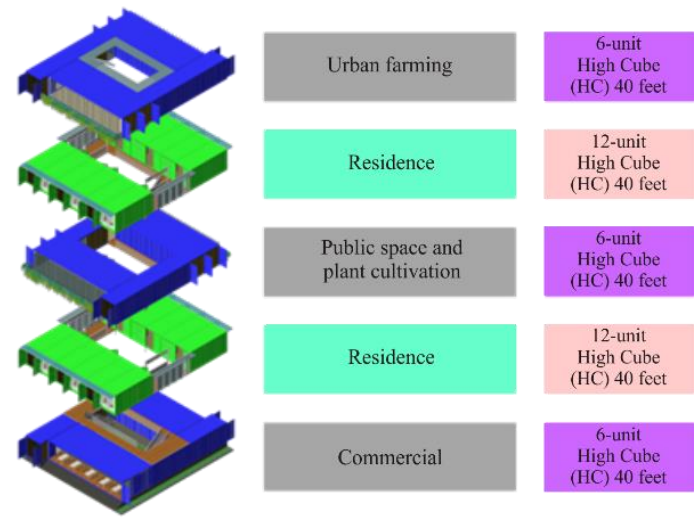

Figure 9. The prototype of rusunawa mass lay out

The following is the prototype result of rusunawa mass based on unit type (table 13).
Table 13. Rusunawa mass prototy pe by unit type

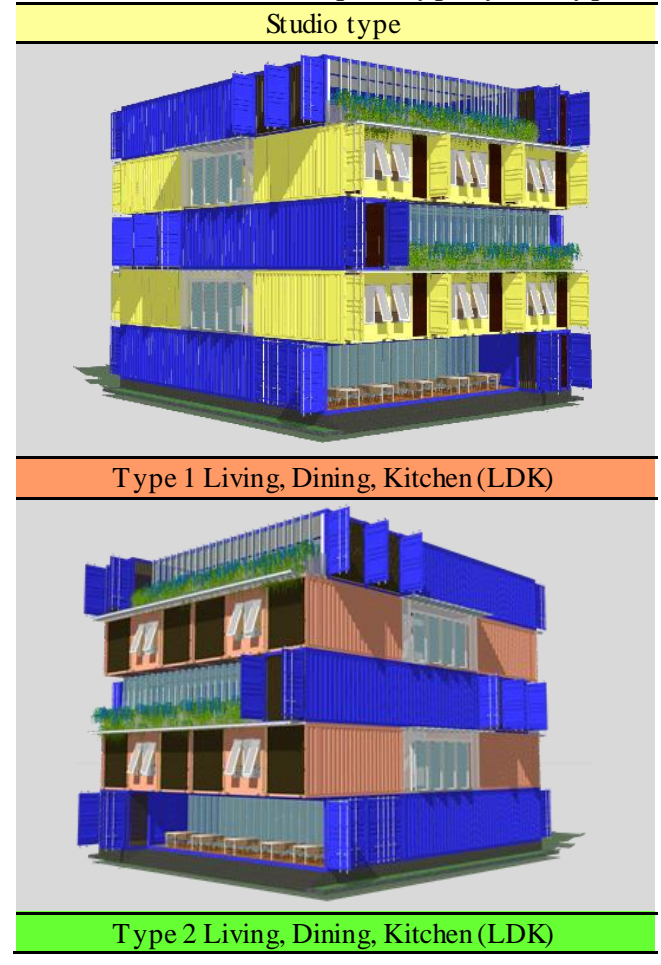




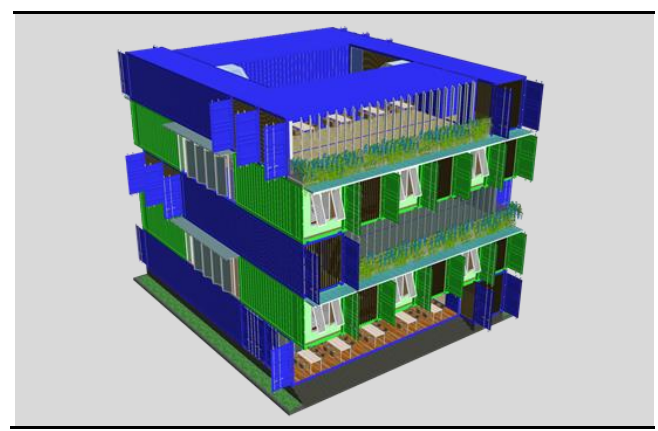

\section{Conclusion}

Reflecting on several case studies, Indonesia needs to utilize reused shipping containers as dwellings. However, there is a need for further study on the construction site, particularly the trans portation of container units and costs, as well as the climatic conditions in the location. The reused shipping container should be used as a technically suitable dwelling, though it should be adapted to environmental conditions.

Future studies should also focus on the social aspects of people living in residential units made from reused shipping containers.

\section{References}

Baur, Xaver, Lygia Therese Budnik, Zhiwei Zhao, Magne Bratveit, Rune Djurhuus, Louis Verschoor, Federico Maria Rubino, Claudio Colosio, and Jorgen R Jepsen. 2015. 'Health Risks in International Container and Bulk Cargo Transport Due to Volatile Toxic Compounds'. Journal of Occupational Medicine and Toxicology 10 (1): 19. https://doi.org/10.1186/s 12995-015-0059-4.

Bender, Stephen. 2016. 'Shipping Containers As A Building Material in Affordable Housing'. In FHCC Day 2 Workshop - Container Housing. https://bndrd.com/wpcontent/uploads/2016/09/FHCC-ContainersDay-2-Workshop-Container-Housing-bndrllc.pdf.

Botes, Antoni Willem. 2013. 'A Feasibi-Lity Study Of Utilising Shipping Containers To Address The Hou-Sing Backlog in South Africa'. Stellenbosch University, South Africa. https://doi.org/10019.1/85714.

Cattani Architects. 2010. 'Cité A Docks Student Housing'. Contemporist. 2010. https://www.contemporist.com/cite-a-docksstudent-housing-by-cattani-architects/.

Estaji, Hassan. 2017. 'A Review of Flexibility and Adaptability in Housing Design'. International Journal of Contemporary Architecture 'The New ARCH' 4 (2): 37-49. https://doi.org/10.14621/tna.20170204.

Habraken, N. John, J. Th. Boekholt, Thijssen, and P. J. M. Dinjens. 1976. Variations: The Systematic Design of Supports. Cambridge, England: The MIT Press.

Hartinisari. 2018. 'Perancangan Rumah Susun Multi Modul'. Bandung. https://simantu.pu.go.id/epel/edok/9e767_Per ancangan_Rusun_menggunakan_Multi_Mod ul.pdf.

Ismail, Mazran, Karam M. Al-Obaidi, Abdul Malek Abdul Rahman, and Mardiana Idayu Ahmad. 2017. 'Con-Tainer Architecture In The Hot-Humid Tropics: Potential And Constrains'. In The 4th International Conference on Environmental Research and Technology, 141-48. Penang, Malaysia: Universiti Sains Malaysia. https://doi.org/10.13140/RG.2.1.1528.4322.

ISO. 2013. ISO 668 - Series 1 Freight Containers. 668 , is sued 2013.

Levinson, Marc. 2006. The Box: How the Shipping Container Made the World Smaller and the World Economy Bigger. New Jersey: Princeton University Press.

Madkour, Mai. 2017. 'Shipping Containers as an Approach to Increase the Quality of Economic Sustainable Buildings in Egypt'. In The 1ST International Conference on TOWARDS A BETTER QUALITY OF LIFE El Gouna. Red Sea Region-EGYPT. El Gouna, Egypt: Housing \& Building National Research Center (HRBC) Technische Universitat Berlin Campus El GOUNA (TUBCG). https://doi.org/10.2139/ssrn.3171827.

Madkour, Mai, and Alaa A. El. 2018. 'Shipping Con-Tainers As A Modular Component For Green Economic Building'. In The Second Memareyat International Conference MIC2018. Egypt: Effat University, Jeddah, KSA.

https://www.researchgate.net/publication/325 023123_Shipping_Containers_as_a_Modular _Component_for_Green_Economic_Building s.

Mahagarmitha, Rilia Rigina. 2018. 'Community Participation in The Development of Kampung Warna-Warni Teluk Seribu In 
Balikpapan City'. ARTEKS: Jurnal Teknik Arsitektur $\quad 3 \quad$ (1): $57-70$. https://doi.org/10.30822/arteks.v3i1.54.

Manaadiar, Hariesh. 2013. 'How Strong Is Your Container Floorboard..??' The Definitive Online Resource for Shipping and Freight Information International Maritime Organization, ISO Container. 2013. https://www.shippingandfreightresource.com /how-strong-is-your-container-floorboard/.

Maya, Fitri. 2018. 'Perpustakaan Amin, Perpustakaan Unik Yang Terbuat Dari Kontainer'. Info Properti News. 2018. https://infoproperti2.wordpres s.com/2016/01/ 08/perpustakaan-amin-perpustakaan-unikyang-terbuat-dari-kontainer/.

Menteri Pekerjaan Umum Republik Indonesia. 2007. Peraturan Menteri Pekerjaan Umum Nomor 05/PRT/M/2007 Tentang Pedoman Teknis Pembangunan Rumah Susun Sederhana Bertingkat Tinggi. Indonesia. http://nawasis .org/portal/digilib/read/peratura n-menteri-pekerjaan-umu m-no mor-05-prt-m2007-tentang-pedoman-teknis-pembangunanrumah-susun-sederhana-bertingkattinggi/51332.

Nunes, N. C. G. 2009. 'Exploitation of Shipping Containers For Housing'. University of Beira Interior.

Pemerintah Pusat RI. 2011. Undang-Undang (UU) Republik Indonesia Nomor 20 Tahun 2011 Tentang Rumah Susun. Indonesia. https://pug-pupr.pu.go.id/_uploads/PP/UU. No. 20 Th. 2011.pdf.

Pisinger, David. 2002. 'Heuristics for the Container Loading Problem'. European Journal of Operational Research 141 (2): 382-92. https://doi.org/10.1016/S03772217(02)00132-7.

Radwan, Ahmed Hosney. 2015. 'Containers Architecture Reusing Shipping Containers in
Making Creative Architectural Spaces'. International Journal of Scientific \& Engineering Research 6 (11): 1562-77. https://www.ijser.org/res earchpaper/Containe rs_Architecture_Reusing_Shipping_Containe rs_in_making_creative_Architectural_Spaces .pdf.

Robinson, Adrian, and Tony Swindells. 2012. 'Customized Container Architecture'. In ACSA Fall Conference 2012, 64-69. https://www.acsa-arch.org/proceedings/Fall Conference

Proceedings/ACSA.FALL.12/ACSA.FALL. 1 2.12.pdf.

Routley, Nick, and Visual Capitalist Creative Director \& Writer. 2018. 'Here's What the Shipping Container Has Done for Globalization'. World Economic Forum. 2018.

https://www.weforum.org/agenda/2018/11/vi sualizing-global-shipping-container-traffic/.

Sanjaya, Wisnu A., and Rumiati Rosaline Tobing. 2019. 'Modular Low-Cost Vertical Housing Benefit from Using Prefabricated Cross Laminated Timber Panel'. ARTEKS : Jurnal Teknik Arsitektur 3 (2): 199-214. https://doi.org/10.30822/arteks.v3i2.70.

Spinks, Rosie. 2019. 'What If the Future of Housing Means Accepting That a Home Isn't Permanent?' Quartz. 2019. https://qz.com/1542887/london-provideslow-income-housing-in-modular-shippingcontainers/.

Woods, Tom. 2015. 'How To Built A Shipping Container Home : The Complete Guide'.

Zberea, Andrei. 2016. 'Container Paradigm: Designing Structures for the Future Lifestyle'. Linnaeus University Dissertations. http://lnu.divaportal.org/smash/record.jsf?pid=diva2\%3A93 $8461 \&$ ds wid $=-5507$. 
ARTEKS : Jurnal Teknik Arsitektur, Volume 6 Issue 1, April 2021

pISSN2541-0598; eISSN2541-1217 